ISSN:

Print - 2277-078X

Online - $2315-747 \mathrm{X}$

(c) FUNAAB 2018

Joumal of

H umanities, Social

Sciences and Creative Arts

\title{
PERCEIVED EFFECT OF COACH ING AND MENTORIN G ON EMPLOYEE JOB PERFORMANCE AMONG ACADEMIC STAFF IN UNIVERSITY OF IBADAN, OYO STATE, NIGERIA
}

\author{
*S.0. ADEOGUN, B.G. ABIONA, 0.S. ALABI, AND J. YILA \\ D epartment of Agricultural Administration, Federal University of Agriculture, \\ Abeokuta Nigeria \\ *Comesponding Author: stephendeog2007@gmail.com Tel: +2347033193684
}

\begin{abstract}
The study assessed the effect of coaching and monitoring on employees' job performance among academic staff in University of Ibadan, Oyo State, Nigeria. Multistage sampling technique was used in obtaining data from ninety academic employees of Faculty of Agriculture University of Ibadan for the study. The data was analysed using Chi square and Pearson Product Moment Correlation. The mean age of the respondents was 51 years while $66.3 \%$ were between ages $51-70$ years, $52.3 \%$ were female and $50.2 \%$ were married. The average year of experience of the respondents was 18.1 years while majority (79.1\%) of the respondents has obtained their PhD degree. On challenges facing coaching and mentoring, respondents identified mentee unwillingness to be mentored $(x=2.84)$, and non conducive environment for coaching and mentoring $(x \rrbracket=2.67)$ as the major constraints, while the least constraint was time and workload pressure $(\mathrm{x} \rrbracket=2.03)$. Many $(62.1 \%)$ of the respondents have high job performance level. There was significant relationship between respondents' marital status and job performance $(P \leq 0.05)$. The study concluded that coaching and mentoring influence employees' job performance positively among academic staff in academic institutions and recommended that provision of good work-environment for coaching and mentoring of academic staff should be provided by university management.
\end{abstract}

Key word: Coaching, Mentoring, Employee, Job Performance and University of Ibadan.

\section{INTRODUCTION}

The development of human resource is important to ensure service quality, effectiveness and responsiveness in an organization to a complex and ever changing business atmosphere (Ramesh, 2015). It is highly accepted that business companies cannot get long term existence without focusing on the practices and strategies for empowering their employees through provision of train- ing and development (Nickson, 2007). Nevertheless, the importance of training to the employees is not just obvious for organizations but also significant for their individual development and empowerment because it is known to improve personal strengths and skills that are necessary for upcoming career development of the individuals (A swathappa, 2007; Ramesh, 2015). There are different types of training, among these are coaching 
*S.O. ADEOGUN, B.G. ABIONA, O.S. ALABI, AND J. YILA

and mentoring which are considered as the spectrum of 'talent management' due to the fact that they either emphasized on the development of special skills that benefit the company as well as the individuals it assists people develop new process of thinking which facilitate people to conquer obstacles and develop their careers through enhancing relationships with more experienced individuals (CIPD, 2014; Ramesh, 2015).

United Kingdom newly-emergent national strategy for continuing professional development strongly advocates the use of coaching and mentoring which create pool of staff who are able to work and extends the opportunity to learn from each other and work with one another(DfEE, 2001) . It also offers the potential to develop learning and teaching practice across the institution to enhance working experience. It is recognized that many individuals have been coached and mentored by their senior colleagues within the University in different ways over many years including directly supporting academic practice enhancement and professional development to acquire desired qualities (Peterson \& al., 2010). Coaching and mentoring of staff can help organizations to enhance employees' performance, improve their strengths, employees' satisfaction, quality of customer service, supervision and overall cost for each employee (Peel, 2004). Armstong (2009) posited that investment in coaching and mentoring in hospitality sectors can have high significance in improving employees' performance since employees' performance is linked to knowledge and skills enhancement, positive attitudes, and improved confidence.

\section{Problem Statement}

One major role of a good university is to turn out graduates that are of good quality in terms of research and development.
There have been complaints of the quality of graduates being produced in Nigerian universities in the recent past compare to what was obtainable years back. The task of producing good and quality graduates of high standard cannot be separated from the quality of lecturers turning out these graduates and their willingness to provide support to young graduates being employed as young academics into the university system in form of coaching and mentoring. In addition, the willingness of these young academic employees of the universities who will later take over from the older ones cannot be overemphasized. According to Solkhe and Chaudhary (2011), human resource being the most vital factor of production requires an integrated coaching and mentoring program for organizational efficiency and effectiveness. Hence, the need for willingness of both the mentors and mentees to be committed to integrated coaching and mentoring programme that will ensure efficiency and effectiveness within the university system. It is in this light that study assessed the effects of mentoring and coaching on employees' job performance at the University of Ibadan.

\section{0 bjectives of the study:}

The main objective was to determine the effect of coaching and mentoring on employees' job performance among academic staff in University of Ibadan, Oyo State, Nigeria. Specific objectives of the study were to:

1. describe socio-economic characteristics of respondents in the study area;

2. identify challenges facing coaching and mentoring among the respondents;

3. determine respondents' opinion of mentoring and coaching effects on academic staff job performance

4. determine level of perceived job perfor- 
PERCEIVED EFFECT OF COACHING AND MENTORING ON EMPLOYEE JOB...

mance of the respondents.

\section{$H$ ypothesis of the study}

There is no significant relationship between respondents' personal characteristics and job performance

\section{METHODOLOGY Scope of the study}

The idea of establishing a Faculty of Agriculture dates back to 1947 when four disciplines (Arts, Science, Medicine, and Agriculture) were incorporated unto then Yaba Higher College that transformed to the University College and was moved to Ibadan. While the faculties of Arts, Science and Medicine took off in 1948, the Faculty of Agriculture took off in 1949. After this time, the Faculty had gone through series of reorganization. However, with the recent reorganization and in accordance with the National University Commission (NUC) recommendation for a 5 - year programmes that have practical of 12 months duration, the degree nomenclature for the 10 new options in the 7 departments are: Agricultural Economics, Agricultural Extension and Rural D evelopment, Agronomy, Animal Science, Crop Protection and Environmental Biology, Forest Resources Management, Wildlife and Fisheries Management

Data for the study was obtained from academic staffs in the Faculty of Agriculture, University of Ibadan, O yo State.

\section{Sampling and sample size}

To obtain the sample size for the study, multistage sampling procedure was used to sample academic staff from University of Ibadan. Faculty of Agriculture and Forestry was purposely selected being the only agricultural based faculty in the University. Seventy percent of the existing 7 departments were randomly selected for the study and lastly $90 \%$ of the 61 senior academic staffs (Professor to Senior Lecturer) and 90\% of 39 junior academic staffs (Lecturer 1 to Graduate Assistant) was selected using simple random sampling technique to give total of 90 respondents representing the sample size for the study. Finally, out of the 90 questionnaire administered, 86 representing $95.6 \%$ of the study instrument.

Job performance: The dependent variable job performance for the study was measured by using four- point Likert type rating scale of very frequently $=4$, frequently $=3$, rarely $=2$ and never $=1$ to measure 12 statements developed to measure the variable. The perceived performance level is in two levels of high and low. The categorization was based on their mean value as follow; High perceived job performance ( $\mathrm{x} \square=31-48$ ), Low perceived job performance $(x \square=12-30)$.

The hypotheses were analysed using Chi square, Pearson Product Moment Correlation (PPMC).

\section{RE SULTS AND DISCUSSION Respondents' socio-economics charac- teristics}

Table 2 presents the socio-economic characteristics of the respondents. The result shows that $38.4 \%$ of the respondents were between ages 51-60 years with mean age of 51 years, this shows that academic staff were still active in service and respondents in this age range are innovative, motivated and adaptable individuals (Fakoya and D aramola, 2005). This also shows that many of the academic staffs have gone beyond being mentored since at this age category, many of the academic staffs are already professors. It could also be an indication that the staffs at the Faculty of Agriculture and Forestry are top heavy. This is also in consonance with the finding of Tsokura and Agwu (2013) 
*S.O. ADEOGUN, B.G. ABIONA, O.S. ALABI, AND J. YILA

who reported the mean age of agricultural lecturers in tertiary institutions to be 42 years.

Table 2 also shows that more than halve (52.3\%) of academic employees were female while the remaining $47.7 \%$ ( were male. This indicated that more female academic employees were in the study area. This indicates that women involvement in academics is as important as men involvement. This finding disagrees with the position of Alarima (2008) that male researchers are prominent in research works and this suggested that agricultural and biological sciences are still dominated by male. This is also contrary to the position of Yusuf $\&$ al. (2010) who reported that of the 3,081 academic staff of the University of Ibadan, 2,574 (83.5\%) were male, while $507(16.5 \%)$ were female giving a sex ratio of about 5:1.

Table 2 further shows that majority $(80.2 \%)$ of the respondents was married, $15.2 \%$ were single, and very few $(2.3 \%)$ were widowed while the remaining $2.3 \%$ were divorced. This implies that there is a positive relationship between age and marital status which implies that at the average age of 51 years most people should ideally be married and settled. This agrees with the finding of Tsokura and Agwu (2013) who reported that majority $(80.3 \%)$ of agricultural lecturers in tertiary institutions are married. Their marital status could impact positively on their job performance and therefore help them to concentrate more on their jobs.

On educational status of the respondents as revealed in Table 2 shows that (79.1\%) of the respondents were $\mathrm{PhD}$ holders. This supports the finding of Yusuf $\&$ al. (2010) that $50.0 \%$ of academic employees had doctorate degrees at the University of Ibadan. While $9.3 \%$ had BSc. degree the remaining $11.6 \%$ of the respondents had MSc. degree. This trend is expected because one of the requirements to be employed as an academic staff in Nigerian universities is possession of a $\mathrm{PhD}$. Those employed with first and second degrees are usually expected to acquire their $\mathrm{PhD}$ degree within the shortest possible period. This has implication on monitoring and coaching of academic employees in that more senior employees are available to mentor the junior academic employees. This is contrary to Tsokura and Agwu (2013) whose study shows that a large proportion $(48.7 \%)$ of agricultural lecturers in tertiary institutions possessed first degree or its equivalent.

The average year of experience of the respondents was 18.1 years. The study shows that $53.5 \%$ of the academic employees in the study area had spent more than 20 years in the system; this suggests availability of sufficient number of academic employees who could mentor and coach junior employees if the later rightly position themselves to be mentored and coached. This is not in agreement with Tsokura and Agwu (2013) who stated that majority $(62.0 \%)$ of the academic lecturers in tertiary institutions had between 1 and 10 years work experience. 
Table 1: Socio-economic characteristics of the respondents $(n=86)$

\begin{tabular}{|c|c|c|c|c|}
\hline Variables & Frequency & Percent & Mean & $\mathrm{SD}$ \\
\hline \multicolumn{5}{|l|}{ Age } \\
\hline$<50$ & 28 & 32.6 & \multirow{4}{*}{51.0} & \\
\hline $51-60$ & 33 & 38.4 & & \\
\hline $61-70$ & 24 & 27.8 & & \\
\hline $71-80$ & 1 & 1.2 & & \\
\hline \multicolumn{5}{|l|}{ Sex } \\
\hline Male & 41 & 47.7 & & \\
\hline Female & 45 & 52.3 & & \\
\hline \multicolumn{5}{|c|}{ Marital Status } \\
\hline Single & 13 & 15.2 & & \\
\hline Married & 69 & 80.2 & & \\
\hline Divorced & 2 & 2.3 & & \\
\hline Widowed & 2 & 2.3 & & \\
\hline \multicolumn{5}{|c|}{ Educational Background } \\
\hline B.Sc. & 8 & 9.3 & & \\
\hline M. Sc. & 10 & 11.6 & & \\
\hline Phd & 68 & 79.1 & & \\
\hline \multicolumn{5}{|c|}{ Years of Experience } \\
\hline$<10$ & 34 & 39.5 & \multirow{5}{*}{18.1} & \\
\hline $10-20$ & 6 & 7.0 & & \\
\hline $21-30$ & 18 & 20.9 & & \\
\hline $31-40$ & 27 & 31.4 & & \\
\hline$>40$ & 1 & 1.2 & & \\
\hline
\end{tabular}

Source: Field survey, 2016

Respondents' opinion of mentoring and coaching effects on academic staff job performance

Table 3 shows that respondents were positively disposed to the fact that mentoring and coaching have significant effects on the employees' job performance. The result shows that respondents opined that state- ments such as university grant opportunities could be improved through proper coaching and mentoring of University academic staff $(\mathrm{x} \square=2.73)$, the tendency for coaching and mentoring to improve staff effectiveness in teaching and learning $(x \square=2.59)$ and the practice of coaching and monitoring has helped to enhance staff' effectiveness in 
*S.O. ADEOGUN, B.G. ABIONA, O.S. ALABI, AND J. YILA

teaching and research $(\mathrm{x} \square=2.73$ ) had sig- Ibadan and has potential to propel the image nificant effects on employees job performance, while statements such as proper mentoring and coaching could contribute to overall performance of the University graduating students $(\mathrm{x} \square=2.22)$, coaching and mentoring has ability to enhances communication and feedback among academic staff $(\mathrm{x} \square=1.96)$ and effective coaching and mentoring can help to increase bond between senior and junior academic staff with overall effect of conflict free work place and high job performance $(\mathrm{x} \square=1.56)$ had the least significant effects on employee job performance.

This implies that coaching and mentoring is encouraged and practice at the University of

and performances of the university academic employees. Generally the study in Figure 1 shows that $82.1 \%$ opined that mentoring and coaching has positive effect on employees' job performance at the University of Ibadan. These findings are consistent with the assertion by Bhatia (2006), that there are many evidences that coaching is very useful to improve performance of the employees, that increases motivation and confidence, develop and improve the skills of leadership and helps people deal with complexities and challenges such as improving relationships, hitting sales targets, making proper decision and team building.

\section{Table 2: Respondents' opinion of mentoning and coaching effects on academic staff job performance}

\begin{tabular}{|c|c|c|}
\hline Statements of respondents' opinion of effects of coaching and mentoring on job performance & Mean & $\mathrm{SD}$ \\
\hline $\begin{array}{l}\text { University grant opportunities could be improved through proper coaching and mentoring of Uni- } \\
\text { versity academic staff }\end{array}$ & 2.73 & 0.57 \\
\hline The tendency for coaching and mentoring to improve staff effectiveness in teaching and research & 2.59 & 0.69 \\
\hline $\begin{array}{l}\text { The practice of coaching and monitoring has helped to enhance staffs' effectiveness in teaching and } \\
\text { research }\end{array}$ & 2.59 & 0.68 \\
\hline Coaching and mentoring can help to increase academic staff visibility & 2.58 & 0.66 \\
\hline Mentee performance in proposal writing can be enhance through the act of mentoring and coaching & 2.53 & 0.65 \\
\hline Teaching and research skills can be improved through mentoring and coaching & 2.47 & 0.65 \\
\hline $\begin{array}{l}\text { Mentoring and coaching can help in improving working relationship between senior and junior aca- } \\
\text { demic staff }\end{array}$ & 2.31 & 0.87 \\
\hline Coaching and mentoring can help to increase academic staff work life balance & 2.30 & 0.67 \\
\hline $\begin{array}{l}\text { Coaching and mentoring could be an effective tool to improve the work environment of academic } \\
\text { staff and make it more conducive }\end{array}$ & 2.26 & 0.78 \\
\hline Effective mentoring and coaching has tendency to promote the image of the University & 2.23 & 0.59 \\
\hline $\begin{array}{l}\text { Proper mentoring and coaching could contribute to overall performance of the University graduat- } \\
\text { ing students }\end{array}$ & 2.22 & 0.76 \\
\hline Coaching and mentoring ability to enhances communication and feedback among academic staff & 1.96 & 0.68 \\
\hline $\begin{array}{l}\text { Effective coaching and mentoring can help to increase bond between senior and junior academic } \\
\text { staff with overall effect of conflict free work place and high job performance }\end{array}$ & 1.56 & 0.78 \\
\hline
\end{tabular}

Source; Field survey 2016

Mean Bench mark: Negative opinion $=x \square=13-32$, Positive opinion ( $x \square=33-52$ ) 


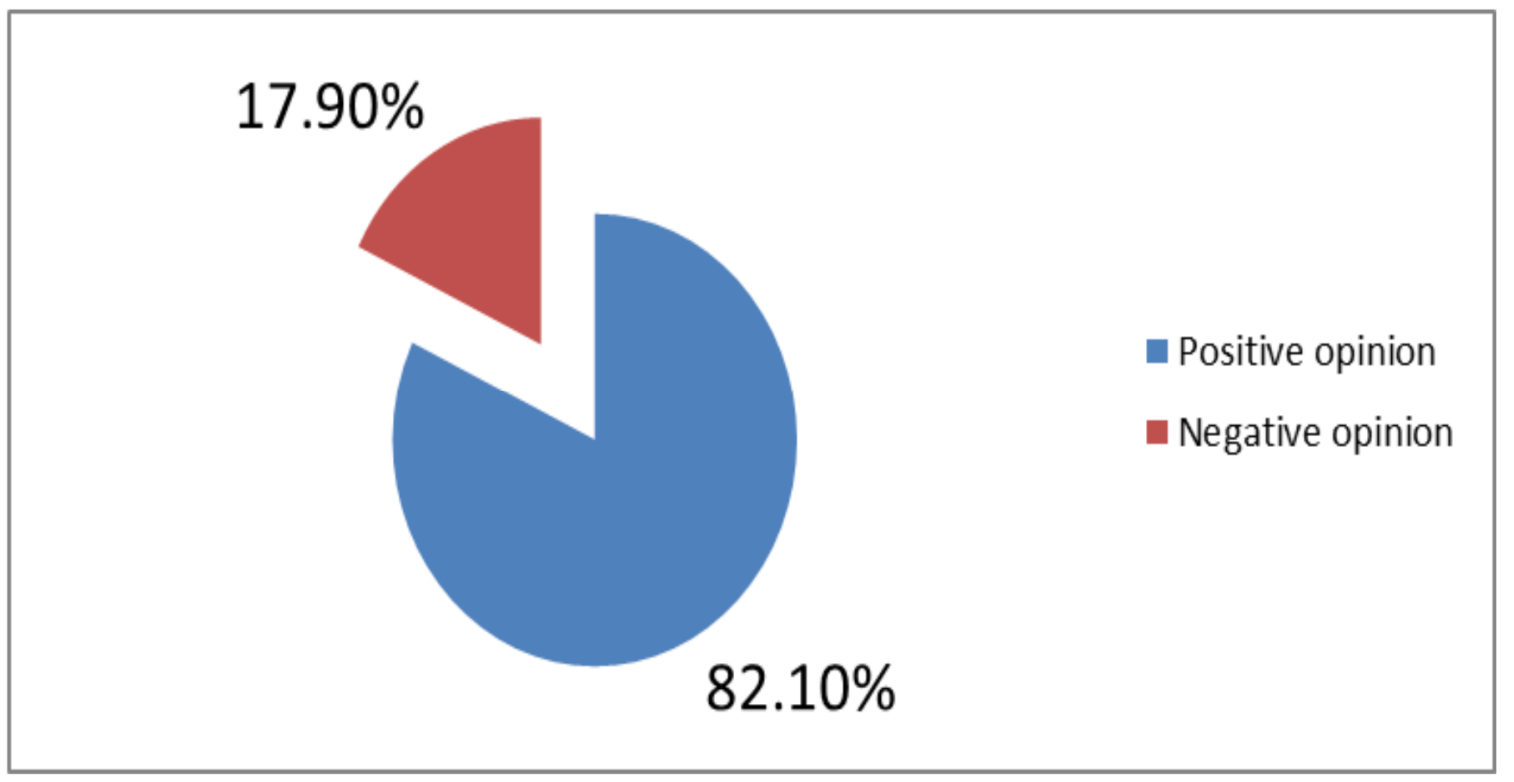

Fig 1: Categorization of respondents' opinion of effects of mentoring and coaching on their job performance

Challenges of Coaching and Mentoring

Table 4 shows that there are numerous challenges facing coaching and mentoring, the most prominent being mentee unwillingness to be mentored ( $\mathrm{x} \square=2.84$ ), nonconducive environment for coaching and mentoring ( $x \square=2.67$ ) and reluctance of staff to take up a supervisory role $(\mathrm{x} \square=$ 2.62). In addition, challenges such as inadequate facilities required by the mentor to coach and mentor mentees, lack of motivation and commitment of the mentees and time and workload pressure had the lowest mean scores of ( $x \square=2.29),(x \square=$ 2.26) and ( $x \square=2.03)$. This implies that the management needs to put in place work environment that will motivate senior staff to mentor and coach younger academic staff while the mentee have to show necessary commitment required for them to be mentored. In summary, $70.8 \%$ of the respondents consider the challenges confronting mentoring and coaching in the university to be severe. 
*S.O. ADEOGUN, B.G. ABIONA, O.S. ALABI, AND J. YILA

Table 3: Challenges facing coaching and mentoring among the respondents $(n=86)$

\begin{tabular}{lll}
\hline Challenges & Mean & S.D \\
\hline Mentee unwillingness to be mentored & 2.84 & 1.05 \\
Non conducive environment for coaching and mentoring & 2.67 & 0.92 \\
Reluctance of staff to take up a supervisory role & 2.62 & 1.00 \\
Mentors efforts to coaching and mentoring of mentee & 2.53 & 1.10 \\
Reluctance of mentees to cooperate and participate in coaching and & 2.51 & 1.15 \\
mentoring activities & & \\
Inability of mentee to take instruction by the mentee & 2.48 & 0.99 \\
Poor relationship between mentor and mentee & 2.47 & 1.07 \\
Academic staff sense of value towards mentorship & 2.43 & 1.05 \\
People being coached may have major interpersonal difficulties & 2.42 & 1.10 \\
Lack of synergy and cooperation among the academic staff & 2.35 & 0.95 \\
Inadequate facilities required by the mentor to coach and mentor & 2.29 & 0.93 \\
mentees & & \\
Lack of motivation and commitment & 2.26 & 1.09 \\
Time and workload pressure & 2.03 & 0.95 \\
\hline
\end{tabular}

Source: Field survey, 2016

Mean Bench mark: Low constraints $(x \square$ value $=13-32)$, High constraints $(x \square$ value $=33-52)$

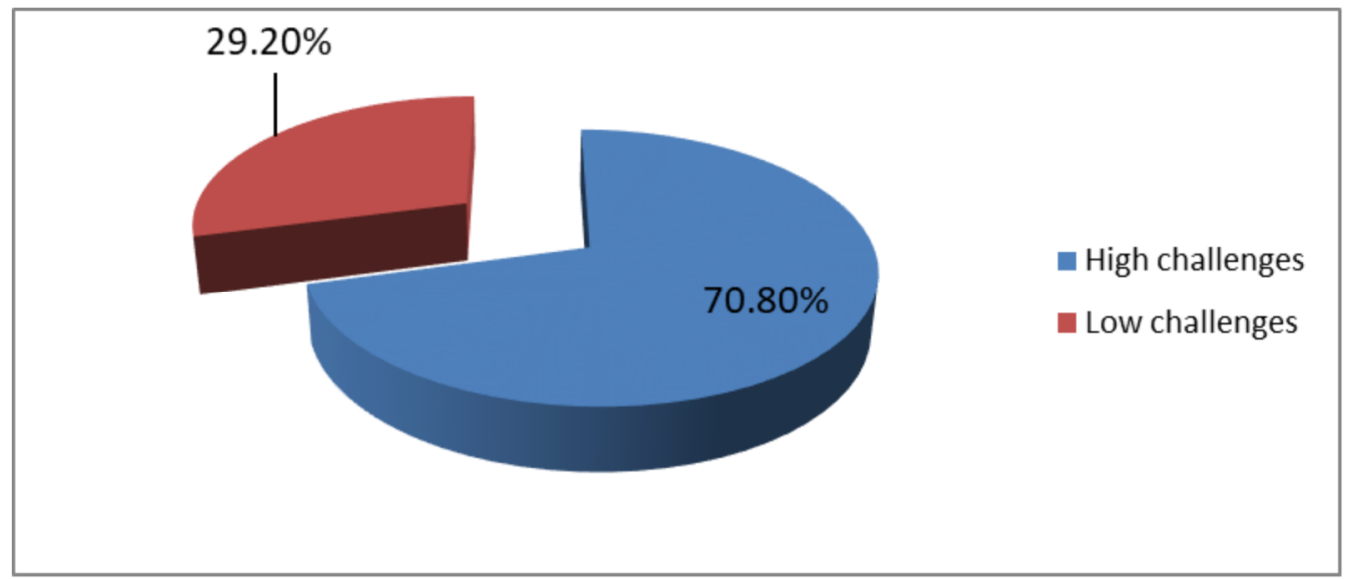

Fig 2: Categorization of challenges affecting mentoring and coaching 


\section{Respondents perceived level of job per- formance}

Table 5 reveals that majority $(77.1 \%)$ of the respondents perceived job performance level of academic employees to be high. Highest mean scores were recorded in statements like I help others resolve disagreements and conflicts $(x \square=2.96)$, I strive towards high degree of skills and proficiency in my work $(x \square=2.93)$, I diligently attend to details and pursue quality in accomplishing tasks assigned to me had the mean scores of $(x \square=2.91)$. This implies that to attain high job performance, the respondents give attention to issues relating to resolving conflicts among employees in the organization. In addition, respondents usually strive for high improved skill, high proficiency and pursuit of quality in assigned tasks is usually given priority.
However, the respondents had the lowest but significantly high mean scores of $(\mathrm{x} \square=2.76)$, ( $\mathrm{x} \square=2.76)$ and $(\mathrm{x} \square=2.67)$ respectively for job performance statements such as I promote cooperation and commitment within a team to achieve goals and deliverables, I encourage team spirit among my colleagues and I carried out assigned duties with little or no supervision. This implies that generally, the respondents perceived the job performance to be very high in the university. This finding supports Van Scotter \& al., (2000) and Sabine \& al. (2010), which established that high performing individuals get promoted, awarded and honored. This makes the career opportunities of individuals that perform well much better than those of moderate or low performing individuals.

Table 4: Perceived level of job performance of the respondents $(n=86)$

\begin{tabular}{lcc}
\hline Job Performance Statements & Mean & SD \\
\hline I help others resolve disagreements and conflicts & 2.96 & 1.36 \\
I strive towards high degree of skills and proficiency in my work & 2.93 & 1.39 \\
I diligently attend to details and pursue quality in accomplishing tasks as- & 2.91 & 1.35 \\
signed to me & & 1.36 \\
I provide sufficient support for my departmental head to succeed in all ram- & 2.87 & \\
ifications. & 2.87 & 1.38 \\
I ensured high level of transparency and accountability & 2.84 & 1.36 \\
Against all odds I try to carry out all assigned duties & 2.35 \\
I maintain confidence and commitment to confront challenges and adapt & 2.82 & 1.35 \\
well to change & 2.82 & 1.39 \\
I ensure timely and early execution of all given assignments & 1.38 \\
Rather that given excuses, i usually think out of the box to ensure i get diffi- & 2.80 & \\
cult problems solved & & 1.38 \\
I promote cooperation and commitment within a team to achieve goals and & 2.76 & \\
deliverables & 2.76 & 1.37 \\
I try to maintain team spirit among my colleagues & 2.67 & 1.40 \\
\hline I carried out duties assigned with little or no supervision &
\end{tabular}

Source: Field survey, 2016

Mean Bench mark: High perceived job performance $(\mathrm{x} \square=31$ - 48), Low perceived job performance $(\mathrm{x} \square=$ $31-48)$ 


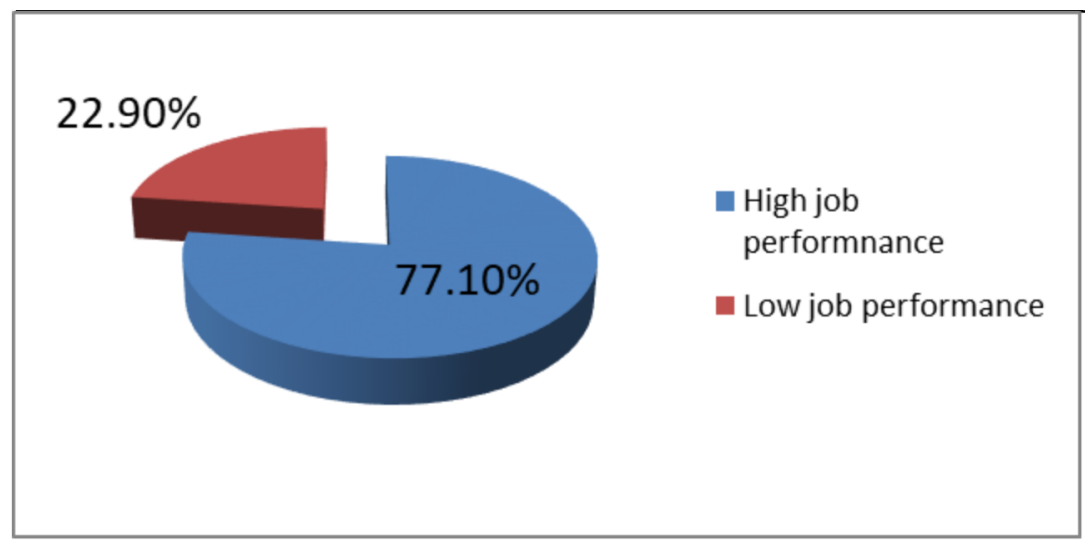

Fig 3: Respondents' perceived job performance level

Test of Hypotheses

Association between socioeconomic characteristics of respondents and job performance

The result of the Chi-square $\left(\chi^{2}\right)$ analysis in Table 6 shows the association between respondents' selected personal characteristic and level of job performance. The results on Table 5 show that marital status $\left(\chi^{2}=90.39, \mathrm{P}<0.05\right)$ was significantly associated with job performance while sex $\left(\chi^{2}=\right.$ 11.89, $\mathrm{P}>0.05)$ and religion $\left(\chi^{2}=21.512\right.$, $\mathrm{P}>0.05)$ were not significant. The significant association between marital status and job performance could be attributed to the fact that married couples encourage themselves to put in more efforts in their jobs.

Table 5: Test of significant association between respondents' socio-economic characteristics and job performance $(n=86)$

\begin{tabular}{lcclc}
\hline Variables & $\chi^{\mathbf{2}}$ & Degree of freedom & Probability level & Decision \\
\hline Sex & 11.890 & 1 & 0.615 & NS \\
Marital Status & 90.391 & 3 & 0.000 & S \\
Religion & 21.512 & 2 & 0.803 & NS \\
\hline
\end{tabular}

Source: Field survey, 2016 
PERCEIVED EFFECT OF COACHING AND MENTORING ON EMPLOYEE JOB...

Significant relationship between re- ship between respondents' age $(p>0.05)$, spondents' socio-economic characteris- years of experience $(p>0.05)$ and perceived tics and perceived job performance

The result of the PPMC analysis in Table 7 job performance.

shows that there was no significant relation-

Table 6: Test of significant relationship between respondents' socio-economic characteristics and job performance $(n=86)$

\begin{tabular}{lcll}
\hline Variable & Correlation(r) value & P-value & D ecision \\
\hline Age & 0.019 & 0.65 & NS \\
Y ears of experience & 0.075 & 0.71 & NS \\
\hline
\end{tabular}

Hypothesis two; There is no significant relationship between

\section{CONCLUSION AND RECOMMENDATIONS}

It was concluded that many of the academic employees have attained level where they are supposed to be mentors and not mentee, which suggests that the academic employees of the Faculty are top heavy. The study further concluded that mentoring and coaching help to promote many cultures among lecturers enhances staff effectiveness and improves learning skills of academic staff. In addition, the study also concluded that the respondents' marital status had significant association with the respondents' perceived job performance, finally, the study shows that respondents positively opined that mentoring and coaching has positive effects on perceived job performance while many respondents indicated that many constraints had severe effects on mentoring and coaching among the academic staff in the study area.

Based on the findings of this study, the following recommendations were made towards ensuring effective coaching and mentoring of academic staff to ensure positive effects on employees' job performance;
Provision of good work environment for coaching and mentoring of academic staff should be provided by university management. Management should provide facilities that will encourage mentoring and coaching among academic employees since they are positively disposed to mentoring and coaching as a mean to promote effectiveness in the institution. Effort should be geared towards minimizing constraints severely affecting monitoring and coaching among academic employees in the university. Such constraints include; time and workload pressure, lack of motivation and commitment and inadequate facilities required by the mentors to coach and mentors' mentees. The management will need to reduce workload pressure by employing more academic employees where necessary. The academic employees appear to be top heavy; hence the need to employ more junior academic staff who could be mentored by those who have acquired more experience on the job.

\section{REFERENCES}

Armstong, M. 2009. A handbook of $\mathrm{Hu}-$ man Resource Management practice (11th ed.). London: Kogan Page Limited. 
*S.O. ADEOGUN, B.G. ABIO NA, O.S. ALABI, AND J. YILA

$1057 \mathrm{p}$

Aswathappa, K. 2007. Human Resource and Personal Management: Texts and Cases (4thed.) India: Tata McG raw-Hill. Pp 87-95

Barber, J. 2004. Skill upgrading within informal training: lessons from the Indian automechanic. International Journal of Training and D evelopment 8 (12), 8-39.

Bhatia, S.K. 2006. Human Resource Management - A Competitive Advantage - Concepts, Strategies, Challenges. India: Jain book Agency. Pp 107-116

Chartered Institute of Personnel Development 2013. Coaching and mentoring: Resource summary. Retrieved from http:/ / www.cipd.co.uk/ hr-resources/ factsheets/ coachingmentoring.aspx 98p

Chartered Institute of Personnel Development 2014. Factsheet: coaching and mentoring, CIPD, London. Retrieved from http:/ / www.cipd.co.uk/ hr-resources/ factsheets/ coaching mentoring.aspx Pp 234

Department for Education and Employment 2001a. Learning and Teaching: a strategy for professional development. London: Stationery O ffice. 125p

Fakoya, E.0., Daramola, B.G. 2015. Socio-economic factors influencing farmers' participation in integrated fish farming. The Journal of Rural Sociology Journal. 5 (3), 78-97

Nickson, D. 2007. Human resource management for hospitality and tourism industries.UK: Elsevier Ltd. 97p

Peel, D. 2004. Coaching and mentoring in

small to medium sized enterprises in the UK -factors that affect success and a possible solution. International Journal of Evidence Based Coaching and Mentoring 2(1): 46-56.

Peterson, S. M., Valk, C., Baker, A.C., Brugger, L. 2010. We"re Not Just Interested in the Work": Social and Emotional Aspect of Early Educator Mentoring Relationship. Mentoring and Tutoring: Partnership in Learning 18(2):155-175

Ramesh, N. 2015. Effect of Coaching and Mentoring on Employee Performance in the UK Hotel Industry. International Journal of Solkhe and Chaudehary, N. (2011). HRD Climate and Job satisfaction. Retrieved from http:/ / dx.doi.org/ 10.5958/ j.2231069x.3.2.007. 89p

Sabine S., Judith V., Anne, S. 2010. Job Performance. Micro approaches Sage handbook of organizational behavior; Julian Barling SAGE Pp 427-447.

Tsokura, A., Agwu, E. 2013. Assessment of Online Resources Usage by Agricultural Science Lecturers of Tertiary Instutions in Benue State, Nigeria. The American Journal of Research Communication. 1(10): 254-279

Van Scotter, J. R., Motowidlo, S. J., Cross, T. C. 2000. Effects of task performance and contextual performance on systemic rewards. The Journal of Applied Psychology Social Sciences and Management. 2 (2): 123-138.

Whitmore, J. 2003. Coaching for Performance, London: Nicholas Brealey Publishing $165 p$

Yusuf, 0. B., A. S. Adebowale, A. F. Fagbamigbe, E. A. Bamgboye., A. B. 0. 
PERCEIVED EFFECT OF COACHING AND MENTORING ON EMPLOYEE JOB...

0. Oyediran 2010. Profile of academic and tional Administration and Policy Studies. 2 senior non-teaching staff in a Nigerian Uni- (7): 92-98

versity. The International Journal of Educa-

(Manuscript received 2ndNowenber, 2017; acceptet 31st May, 2019). 